\title{
Udviklingen af kynisme fra politistuderende til betjent
}

\author{
fokus på kynismens delaspekter og arbejdsmæssige \\ faktorer ${ }^{1}$
}

Christian Dyrlund Wåhlin-Jacobsen, Adjunkt, cand.psych., ph.d. Institut for Organisation, Copenhagen Business School \& Elisabeth Naima Mikkelsen, Lektor i organisationspsykologi, PhD, Institut for Organisation, Copenhagen Business School

\begin{abstract}
The literature shows that some police officers develop cynicism early in their careers, i.e., develop a critical or distrusting attitude that is often aimed towards citizens. Despite a recent increase in societal focus on how citizens experience interaction with the police, we have only a limited understanding of how cynicism develops in Scandinavia, including Denmark. In this study, we present statistical analyses of questionnaire data collected among police employees in three waves between the beginning of their training to become police officers and after four years of active service. The results demonstrate that cynicism should be approached as a multi-faceted phenomenon. This is because participants generally report a decrease in cynicism towards citizens, but an increase in cynicism in connection with other aspects of police work. Post hoc analyses, however, indicate that high emotional demands, as well as violence and threats may contribute to an increased cynicism towards citizens.
\end{abstract}

\section{Keywords}

cynicism, police, career studies, emotional demands, violence and threats

\section{Nøgleord}

kynisme, politi, karrierestudier, følelsesmæssige krav, vold og trusler

\section{Indledning}

Bliver politistuderende mere kyniske i takt med, at de færdiggør deres uddannelse og begynder at arbejde som politibetjente? Det mener langt det meste internationale politiforskning (se f.eks. Behrend, 1980; Enciso et

1. Title in English: The development of cynicism among police students and in the first years of police service: attending to the different aspects of cynicism and work-related factors 
al., 2017; Lotz og Regoli, 1977; Niederhoffer, 1967; Sobol, 2010), der igennem en lang årrække har haft stor teoretisk og empirisk interesse i at undersøge kynisme i politiet, særligt hvorfor kynismen opstår, og hvilke konsekvenser den får for politiarbejdet. Som arbejdspsykologisk fænomen kan kynisme defineres som en 'attitude, characterized by frustration and disillusionment as well as negative feelings toward and distrust of a person, group, ideology, social convention, or institution' (Andersson og Bateman, 1997, s. 450). I denne forstand er kynisme altså en særlig kritisk indstilling præget af mistro eller pessimisme, som man kan have til sit arbejde eller dele af det. Forskningen fremhæver, at politifolk ofte ser mennesker fra deres værste side, hvilket kan medføre en tro på, at intet af det, de gør, gør en forskel, og til sidst mister de deres evne til at føle empati for andre mennesker og bliver kyniske (Caplan, 2003; Edge et al., 1980; Niederhoffer, 1967). Hvor kynismen kan være rettet mod politiet som arbejdsplads og de forhold, opgaverne skal løses under, er det særligt kynisme rettet mod borgerne, som har været genstand for undersøgelser og debat. Kynisme er således centralt i forhold til politiets kontakt med borgerne.

Politiets interaktion med borgerne er højt prioriteret på den politiske dagsorden i Danmark, med mål om at fremme en serviceorienteret tilgang, hvor politiet bliver oplevet som åbent, nærværende og tilgængeligt og sætter borgeren i centrum (Justitsministeriet, 2017, 2018). Dansk politi har en generelt høj og relativt stabil tillid fra borgerne (Rigspolitiet, 2020), både i sammenligning med det øvrige Skandinavien, Europa og eksempelvis USA (Justitsministeriets Forskningskontor, 2016; Gallup, 2020). ${ }^{2}$ Men samtidig peger en nyere undersøgelse på, at 17 \% af de borgere, der har været i kontakt med politiet, er utilfredse med politiets ageren (Justitsministeriets Forskningskontor, 2018). For nogle grupper er disse tal endnu højere: eksempelvis er $22 \%$ blandt ofre for kriminalitet utilfredse.

Kynisme i politiet er vigtig at undersøge, fordi politifolks indstilling til borgerne og politiarbejdet påvirker deres engagement og adfærd, og dermed måden, de udfører deres opgaver på. Dog er meget kynismeforskning af ældre dato og foretaget i lande med en politikultur, der adskiller sig væsentligt fra de nordiske. Ofte er forskningen kendetegnet ved vigtige metodologiske svagheder, der gør det svært reelt at sige noget om hvordan kynisme udvikler sig.

I denne artikel vil vi derfor undersøge udviklingen i kynisme og dennes delaspekter ved at følge de samme politifolk over en syvårig periode. Vores studie er unikt i nordiske og internationale sammenhænge, fordi det som det første anvender longitudinale data fra den danske del af RECPOL-undersøgelsen (Recruitment, Education and Careers in the Police) til at undersøge hvordan kynisme hos politistuderende udvikler sig fra uddannelsesstart til ca. fire år inde i arbejdslivet som betjent, og om ændringen i kynismen er rettet mod borgerne, det strafferetslige system eller politiets arbejdsmeto-

2. Undersøgelserne bruger dog forskellige metoder, hvilket gør, at en direkte sammenligning ikke er muligt. 
der. Udover at afdække udviklingen i kynisme, undersøger vi om en række forhold ved politiarbejdet bidrager til, at den enkelte udvikler kynisme mod borgerne. Vi præsenterer indledningsvist, hvordan man teoretisk og metodemæssigt har tilgået kynisme i den internationale politiforskning. Derefter beskriver vi vores data, metode og analysedesign, hvorefter resultaterne gennemgås. Vi slutter artiklen med at diskutere studiets relevans for teori og praksis.

\section{Kynisme i politiet}

Tidlig politiforskning interesserede sig især for kynisme rettet mod borgerne og anså derfor kynisme som en slags mistro over for den menneskelige natur, der udviklede sig i takt med, at betjentene fik mere arbejdserfaring (Behrend, 1980). Efterhånden som de oplevede konflikter og manglende respekt fra offentligheden, udviklede de en kynisk indstilling til deres arbejde, som udhulede deres tillid til politiets idealer (Edge et al., 1980; Niederhoffer, 1967). Megen politiforskning antager, at kynisme er en rodfæstet del af politiets kultur, som manifesterer sig som en mistænksom, endda fjendtlig tilgang til borgerne (Behrend, 1980; Graves, 1996). Andre ser kynisme som et nødvendigt element i politiets kultur, men påpeger at det opstår som en form for coping med krav og belastninger, der er i politiarbejdet, samt den hierarkiske organisering som betjentene er en del af (Caplan, 2003; Enciso et al., 2017; Hunt, 1985; Sobol, 2010). Langt det meste forskning anser således kynisme for at være en mere eller mindre universel indstilling, som politifolk udvikler over for borgerne, uanset det omgivende samfund.

\subsection{Udviklingen af kynisme hos politifolk}

Niederhoffer (1967) var blandt de første til at undersøge kynisme i politiet. Han gennemførte en undersøgelse i New Yorks politidistrikt (NYPD), hvor han målte kynisme hos både rekrutterne tidligt i deres skoleforløb og blandt politifolk i beredskabet med op til ca. 20 års erfaring. Mens der blev fundet kynisme i næsten alle de undersøgte grupper, sås der en tydelig sammenhæng mellem anciennitet og kynisme: tidligt i rekrutternes karriereforløb steg kynismen og toppede så efter syv-ti års erfaring, for derefter at falde frem til betjentene gik på pension. Niederhoffer fremhævede rekrutternes socialisering ind i den eksisterende politikultur samt apati, frustration og fremmedgørelse som de vigtigste forklaringsfaktorer for den stigende kynisme.

Ifølge Niederhoffer udgjorde kynisme og professionalisme hver sin pol på et kontinuum af politifolks indstillinger til deres arbejde. Når politifolk f.eks. oplevede mangel på respekt fra borgerne, eller at deres overordnede ikke støttede dem, blev de mindre professionelle og mere kyniske. En række stu- 
dier ledet af Regoli i 1980erne fandt samme relation mellem professionalisme og kynisme og fremhævede at kynisme skulle anses som en vigtig forklaringsfaktor for korruption og anden ureglementeret adfærd blandt politifolk (Lotz og Regoli, 1977; Regoli et al., 1987).

Det særligt interessante ved Niederhoffers (1967) undersøgelse er, at han fandt ud af, at politirekrutter udviklede kynisme tidligt i deres uddannelsesforløb. Han forklarede dette med, at politirekrutter i starten af deres karriere er orienteret mod at hjælpe folk og føler sig meget forpligtet til at udføre politiarbejdet på en professionel måde. Men når de gentagne gange oplever, at de skal håndtere fjendtligt indstillede borgere, bliver de desillusionerede og udvikler kynisme. Lignende pointer har været fremhævet i nyere skandinavisk forskning, der viser, at politistuderende oplever konflikter mellem deres værdier og holdninger på den ene side, og dét som opfattes som nødvendigt for at kunne begå sig i politiarbejdet på den anden side (Fekjær et al., 2014; Hove, 2012). Nyere studier har dog påvist lavere niveauer for kynisme blandt politirekrutter (Mignone, 2005), og at rekrutterne har meget høje etiske standarder, er altruistisk motiverede, og vil gøre en forskel for andre mennesker (Ford, 2003; Sundström og Wolming, 2014). Thomassen, Larsson og Strype (2008) fandt for eksempel, at norske politistuderende var mindre kyniske ved slutningen af uddannelsen, end da de startede. Noget tyder altså på, at udviklingen af kynisme varierer på tværs af tid og sted.

I tråd med dette kritiserer Kääriäinen og Sirén (2012), at man i litteraturen hovedsageligt har undersøgt kynisme hos politifolk i større byer i USA og Storbritannien. I stedet undersøgte de politiets kynisme rettet mod borgerne i 22 europæiske lande. Ved at sammenligne graden af tillid til andre mennesker hos henholdsvis politifolk og i den brede befolkning, kunne de vise, at politiets tillid til borgerne afspejler niveauet i resten af samfundet. Politifolkene rapporterede dog generelt lavere tillid. I et andet studie af politistuderende på tværs af europæiske lande inklusive Danmark, fandt man ligeledes, at politistuderende har lidt lavere tillid til andre mennesker sammenlignet med den nationale baggrundsbefolkning (Thomassen og Strype, 2020). Forfatterne mener, at resultatet kan skyldes en selektionseffekt i forhold til hvem, der ansøger og bliver optaget på politiskolen.

\subsection{Målingen af kynisme hos politifolk}

Niederhoffer (1967) udviklede en skala til måling af kynisme i politiet, som efterfølgende er blevet brugt i en række studier af sammenhænge mellem kynisme i politiet og uddannelse, anciennitet, job tilfredshed, frustration og stress (se f.eks. Travis og Vukovich, 1990; Richardsen et al., 2006). I tråd med Niederhoffer har disse studier konkluderet, at faktorer, der korrelerer med kynisme typisk ligger uden for den individuelle betjent, for eksempel arbejdsforhold. Niederhoffers skala er dog blevet kritiseret for at måle kynisme som 
et endimensionelt fænomen, og adskillige undersøgelser har sidenhen påvist at kynisme er mangesidet (Langworthy, 1987; Regoli, 1976). Regoli, Crank, og Rivera (1990) har derfor udviklet en skala, der specificerer hvor kynismen er rettet mod, og i et nyligt studie har Thomassen og Strype (2020) demonstreret, at denne skala måler tre underliggende faktorer, der svarer til henholdsvis kynisme som rettet mod borgerne (som hos Niederhoffer), samt mod det strafferetslige system og politiets arbejdsmetoder.

Et andet kritikpunkt i forhold til den tidlige kynismeforskning er, at bl.a. Niederhoffers konklusioner er baseret på tværsnitsdata, mens en reel måling af udviklingen i kynisme over tid kræver longitudinale data, der følger samme personer for at udelukke en eventuel kohorte-effekt. Til dato findes kun to studier af kynisme, der har anvendt longitudinale data i henholdsvis USA (Encisco et al., 2017) og blandt en gruppe europæiske (primært nordiske) lande (Thomassen og Strype, 2020). Mens begge studier målte kynisme i stikprøver af politistuderende når de påbegyndte og afsluttede deres uddannelse, tilføjede Encisco et al. (2017) en tredje måling ved også at måle deres kynisme seks måneder inde i arbejdslivet, dvs. efter ganske kort tids arbejdserfaring.

Dog målte Encisco et al. (2017) kun en enkelt underdimension af kynisme, nemlig organisatorisk kynisme, som retter sig mod politiets ledelse og hierarkiske organisering. Med afsæt heri bekræfter de Niederhoffers oprindelige påstand om, at kynismen generelt stiger støt fra første dag på politiskolen frem til seks måneder efter uddannelsens afslutning. Studiet af Thomassen og Strype (2020) fokuserer derimod som nævnt på tre underdimensioner af kynisme, hvor der i nogen grad ses forskellige udviklinger i de inkluderede lande. Blandt de nordiske lande ses der eksempelvis, at kynismen mod borgerne er nogenlunde konstant i Danmark, let faldende i Sverige og stigende i Norge. I forhold til retssystemet ses stigende kynisme i Danmark mod faldende i Sverige og Norge, og i forhold til politiets metoder ses generelle fald. Thomassen og Strype undersøger dog kun udviklingen i kynisme i løbet af selve politiuddannelsen, hvilket kan være problematisk fordi politistuderende i de nordiske lande kun har haft begrænset erfaring med politiarbejde, hvilket forfatterne også fremhæver. Ud over den begrænsede opfølgningsperiode inkluderer de nævnte studier heller ikke analyser, der kan pege på, hvilke faktorer, der konkret bidrager til en eventuel stigning (eller fald) i kynismen hos den enkelte.

Vi undersøger derfor, hvordan kynisme udvikler sig fra uddannelsesstart til ca. fire år inde i arbejdslivet som politibetjent, og om ændringen i kynisme er rette mod borgerne, det strafferetslige system eller politiets arbejdsmetoder. Vi vil konkret undersøge følgende hypoteser:

H1a: Respondenternes holdninger udvikler sig i retning af øget kynisme generelt

H1b: Respondenternes holdninger udvikler sig i retning af øget kynisme i forhold til borgerne 
Derudover har den tidligere forskning som nævnt peget på, at betjentenes oplevelser med borgerne efter uddannelsen har betydning for udviklingen af kynisme, men dette er ikke undersøgt longitudinalt. Ud fra litteraturen er det sandsynligt, at eksempelvis krav om at skulle håndtere egne eller borgeres vanskelige følelser, trusler eller vold kan bidrage til udviklingen i kynisme. Vi ønsker derfor også at undersøge følgende hypotese:

H2: Respondenter, der i høj grad har været udsat for følelsesmæssige krav, vold og trusler, vil i højere grad udvikle kynisme rettet mod borgerne

De undersøgte sammenhænge er illustreret i Figur 1.

Fase 1

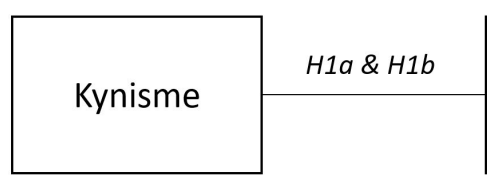

Fase 2

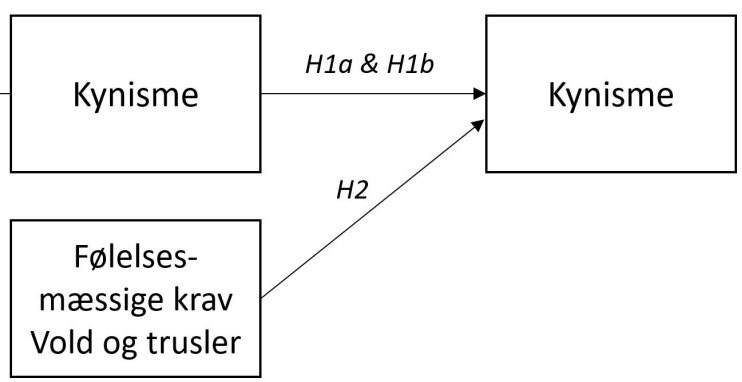

Figur 1: Konceptuel model for de statistiske analyser

\section{Data og metode}

\subsection{Undersøgelsesdesign}

Analyserne i denne artikel er som nævnt baseret på data fra den danske del af RECPOL-undersøgelsen, der har været beskrevet af bl.a. Bjørgo og Damen (2020). Undersøgelsen indeholder både spørgsmål, der er fælles for de deltagende nationer, og spørgsmål der er udvalgt ud fra en dansk kontekst. Dataene i denne artikel stammer fra de første årgange, der har gennemført undersøgelsens første, anden og tredje fase i henholdsvis 20122013, 2015-2016 og 2019. ${ }^{3}$ Deltagerne var studerende på de fire første optag på den treårige professionsbacheloruddannelse $\left(\mathrm{N}_{\text {Fase } 1}=359, \mathrm{~N}_{\text {Fase } 2}=340\right.$, $\mathrm{N}_{\text {Fase } 3}=178$ ). Svarprocent for de tre faser er henholdsvis $92,3 \%, 87,1 \%$ og 53,4 \% (personlig kommunikation med Politiskolen, 2020-2021).

\subsection{Spørgeskemaopbygning}

RECPOL-spørgeskemaet indeholder spørgsmål vedrørende en række forskellige emner. Som baggrundsvariable til at beskrive deltagerne anven-

3. Det bemærkes, at mens der for alle deltagere er ca. tre år mellem besvarelsen af Fase 1 og Fase 2, er der lidt større forskelle mellem, hvor lang tid, der går fra besvarelsen af Fase 2 til Fase 3: mellem ca. tre et halvt år og fire år. 
des der fra første spørgeskemafase spørgsmål om deltagernes alder, køn, fødeland og tidligere uddannelse. Fra Fase 3 anvendes et spørgsmål om, hvilken funktion deltagerne arbejder i. I forhold til kynisme anvendes for alle tre runder otte spørgsmål fra Regolis skala (Regoli et al., 1990), for eksempel: »Mange borgere har en negativ holdning over for politifolk« (se bilag 8.1 for en komplet liste). Spørgsmålene besvares ud fra fire svarkategorier, rækkende fra »helt uenig" (1) til »helt enig" (4). Til at undersøge følelsesmæssige krav anvendes 11 spørgsmål, der indgår i undersøgelsens Fase 2, for eksempel: »Mit arbejde kræver, at jeg skal skjule, hvad jeg egentlig føleru (se bilag 8.2 for en komplet liste). Spørgsmålene blev besvaret ud fra fire svarkategorier, fra »slet ikke« (1) til »i høj grad« (4). I forhold til vold og trusler anvendes otte spørgsmål, der også kun indgår i undersøgelsens Fase 2, for eksempel: „Har du i løbet af dine praktikperioder været udsat for trusler om vold? « (se bilag 8.3 for en komplet liste). Spørgsmålene blev besvaret ud fra fire svarkategorier: »nej, aldrig« (1), »ja, en gang« (2), »ja, enkelte gange« (3) og »ja, adskillige gange« (4).

\subsection{Statistiske analyser}

Til at undersøge $\mathrm{H} 1 \mathrm{a}$ og $\mathrm{H} 1 \mathrm{~b}$ anvendtes en ANOVA-analyse med gentagne målinger, hvor deltagerne blev koblet på løbenummer. I analysen fokuserede vi på, om der samlet er en statistisk signifikant effekt af tid på de estimerede scorer, og vi analyserede på kontraster mellem de estimerede gennemsnitsscores på tværs af de enkelte faser ud fra t-tests.

Til at undersøge $\mathrm{H} 2$ anvendtes trinvis regression. I første trin modellerede vi effekten af respondenternes niveau af kynisme i Fase 2 på scoren i Fase 3 (kontinuert: gennemsnitlig skalascore). Hensigten med dette var at analysere på udviklingen i kynisme, og ikke forskelle i den enkeltes niveau. Vi inkluderede også baggrundsvariablene alder (kontinuert: antal år), køn (dummy: mand = 0 , kvinde $=1$ ), samt deltagerens hold på Politiskolen (dummy: ikke deltager = 0 , deltager =1). I Fase 2 inkluderede vi yderligere følelsesmæssige krav (kontinuert: gennemsnitlig skalascore), vold og trusler (kontinuert: gennemsnitlig skalascore), samt funktionskategorier (dummy: ikke ansættelse i kategori $=$ 0 , ansættelse $=1$ ).

Vi gennemførte vores analyser om kynismens facetter ud fra Thomassen og Strypes (2020) tre-faktor model, der opdeler Regoli-skalaen i kynisme rettet mod henholdsvis borgerne, retssystemet eller politiets metoder. ${ }^{4}$ De anvendte spørgsmål om følelsesmæssige krav er så vidt vi ved ikke tidligere skalavalideret. Vores analyser peger på, at besvarelserne kan skaleres (Cronbachs $\alpha$ $=0,74$; alle item-test korrelationer $>0,3$ ). Det samme gælder spørgsmålene om vold og trusler, om end Cronbachs $\alpha$ var lavere $(0,68$; alle item-test korrelationer $>0,3$ ).

4. Vi opnår dog lidt lavere Cronbach's $\alpha$ : henholdsvis 0,68 (borgere), 0,48 (systemet) og 0,58 (metoder) i Fase 1. 
Som frafaldsanalyse blev der, jf. Goodman og Blum (1996), gennemført en logistisk regression med frafald som afhængig variabel og med de ovennævnte baggrundsvariable samt kynisme, både samlet og som enkelte facetter, som uafhængige variable. Efterfølgende gennemførtes t-test af gennemsnit for uafhængige grupper (respondenter med komplette besvarelser vs. frafaldne) for hver uafhængige variabel. Testene blev specificeret til at tillade forskellig varians blandt henholdsvis respondenter med komplette besvarelser og frafaldne.

Alle analyser blev gennemført i Stata ved brug af funktionerne logit, ttest, anova, regress og alpha (StataCorp, 2019).

\section{Resultater}

\subsection{Baggrundsvariable og frafaldsanalyse}

I Tabel 1 præsenteres baggrundsdata om deltagerpopulationen.

\begin{tabular}{|c|c|c|}
\hline Kategori & Værdi & Noter \\
\hline Alder (ved Fase 1 & Gennemsnit: 25,9 år & Beregnet ud fra Fase 1-svar \\
\hline \multirow[t]{2}{*}{ Køn } & Mand: 75,6\% & Beregnet ud fra Fase 1-svar \\
\hline & Kvinde: $24,4 \%$ & \\
\hline \multirow[t]{2}{*}{ Fødeland } & Danmark: 97,2 \% & Beregnet ud fra Fase 1-svar \\
\hline & Andet: $2,8 \%$ & \\
\hline \multirow[t]{5}{*}{ Højeste gennemførte uddannelse } & Gymnasial: 62,2 \% & Beregnet ud fra Fase 1-svar \\
\hline & Erhvervsuddannelse: 15,9\% & \\
\hline & Kort videregående: 6,5% & \\
\hline & Mellemlang videregående: 10,5 \% & \\
\hline & Lang videregående: 4,8 \% & \\
\hline \multirow[t]{6}{*}{ Funktion } & Beredskabet: 49,4 \% & Beregnet ud fra Fase 3-svar \\
\hline & Operativ specialenhed: $21,3 \%$ & \\
\hline & Efterforskning: $19,1 \%$ & \\
\hline & Administration og ledelse: 4,5\% & \\
\hline & Forebyggelse: 3,9\% & \\
\hline & Efterretning og analyse: 1,7 \% & \\
\hline
\end{tabular}

Tabel 1: Baggrundsdata om deltagerpopulationen.

Den logistiske regression viste, at frafaldet ikke var forklaret af de uafhængige variable (Chi-square: 19,8; $p>0,05$ ). Dog sås der statistisk signifikante forskelle mellem gennemsnitlig kynisme i forhold til retssystemet ved Fase $1(2,22$ vs. 2,33; $t=-1,92(327,5), p<0,05)$, og at andelen af kvinder var $h \varnothing-$ jere blandt de frafaldne end fuldførende deltagere $(17,3 \%$ vs. $29,9 \%$; $t=$ $-2,83(353,5), p<0,01)$. 
4.2. Udvikling i samlet kynisme og kynismens tre delaspekter

Resultaterne i forhold til hypoteserne H1a og H1b præsenteres i Figur 2.
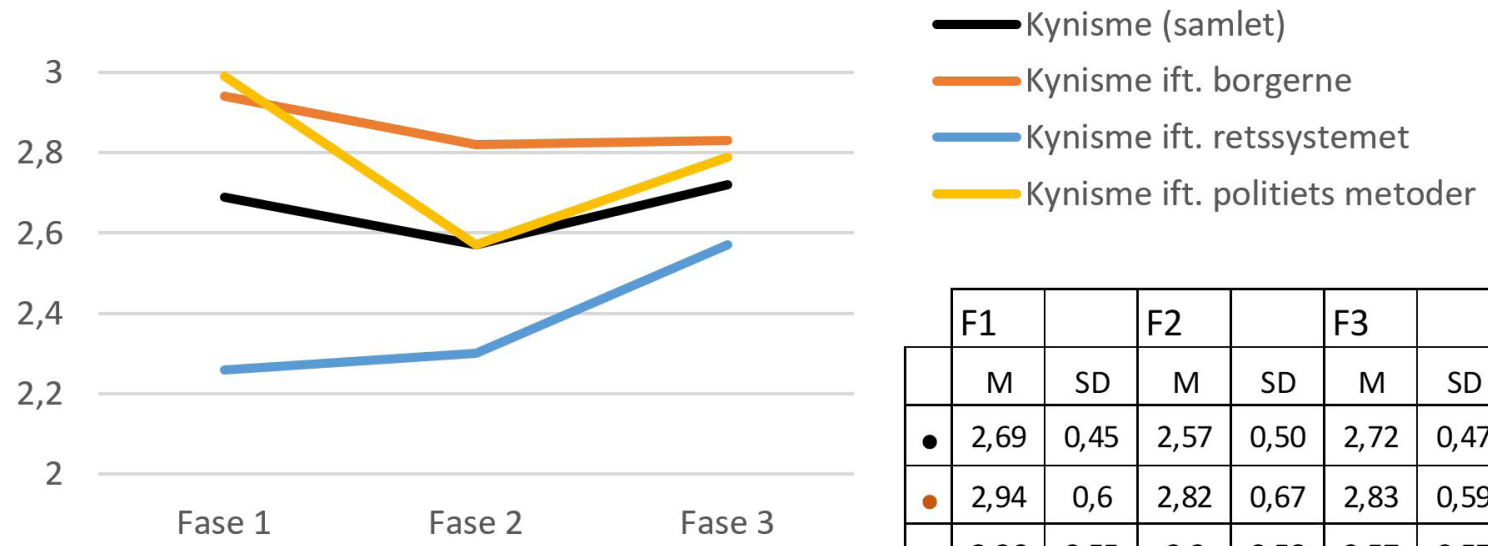

\begin{tabular}{|c|c|c|c|c|c|c|}
\cline { 2 - 7 } \multicolumn{1}{c|}{} & F1 & & F2 & & F3 & \\
\hline & M & SD & M & SD & M & SD \\
\hline$\bullet$ & 2,69 & 0,45 & 2,57 & 0,50 & 2,72 & 0,47 \\
\hline$\bullet$ & 2,94 & 0,6 & 2,82 & 0,67 & 2,83 & 0,59 \\
\hline$\bullet$ & 2,26 & 0,55 & 2,3 & 0,58 & 2,57 & 0,57 \\
\hline$\bullet$ & 2,99 & 0,81 & 2,57 & 0,9 & 2,79 & 0,93 \\
\hline
\end{tabular}

Figur 2: Resultater af repeated measures ANOVA. Høje scorer indikerer høj kynisme. Figuren viser værdierne, som de er estimerede af modellen, og altså ikke et simpelt gennemsnit.

Analysen viser et fald i deltagernes samlede kynisme mellem Fase 1 og $2(-0,12 ; \mathrm{p}$ $<0,001)$, og derefter en stigning mellem Fase 2 og $3(0,15 ; p<0,001)$, til et niveau svarende til det ved Fase 1. Men der ses ikke en samlet stigning i deltagernes kynisme over alle tre faser $(0,03 ; p=0,55)$, og hypotese 1a forkastes derfor.

I forhold til kynisme i forhold til borgerne sås først et fald mellem Fase 1 og $2(-0,12 ; p<0,01)$ og herefter en stabil udvikling mellem Fase 2 og $3(0,01 ; p$ $=0,85)$. Da kynismen rettet mod borgerne samlet set var faldende $(-0,11 ; p=$ 0,05), forkastes også hypotese 1b.

Det bemærkes, at der for både kynisme rettet mod retssystemet og mod politiets metoder sås stigende kynisme mellem Fase 2 og 3 (henholdsvis 0,27; $p<0,001$ og 0,22; $p<0,01)$. For kynisme i forhold til politiets metoder sås desuden et betydeligt fald i kynismen mellem Fase 1 og $2(-0,42 ; p<0,001)$. Det er således sandsynligt, at den »U«-formede udvikling, der sås for kynisme generelt, i høj grad skyldes udviklingen på disse sidste to delaspekter.

\subsection{Følelsesmæssige krav, vold og truslers betydning for udviklingen i}

kynisme rettet mod borgerne

Resultaterne af regressionsanalysen i forhold til $\mathrm{H} 2$ findes i Tabel 2.

\begin{tabular}{|l|ccccc|}
\hline & $b$ & Std. error & $\beta$ & $t$ & $p$ \\
\hline Første trin (justeret R2: 0,166): & & & & & \\
Kynisme mod borgerne i Fase 2 & 0,34 & 0,07 & 0,40 & 5,16 & $<0,001$ \\
Skolehold 2 & $-0,07$ & 0,13 & $-0,05$ & $-0,56$ & 0,57 \\
Skolehold 3 & $-0,19$ & 0,13 & $-0,14$ & $-1,47$ & 0,14 \\
Skolehold 4 & $-0,22$ & 0,13 & $-0,16$ & $-1,65$ & 0,10 \\
Alder & 0,00 & 0,01 & 0,01 & 0,13 & 0,89 \\
Kvinde & 0,19 & 0,12 & 0,12 & 1,56 & 0,12 \\
\hline
\end{tabular}




\begin{tabular}{|c|c|c|c|c|c|}
\hline & $b$ & Std. error & $\beta$ & $t$ & $p$ \\
\hline \multicolumn{6}{|l|}{ Andet trin (justeret R2: 0,175): } \\
\hline Følelsesmæssige krav & $-0,05$ & 0,11 & $-0,04$ & $-0,46$ & 0,65 \\
\hline Vold og trusler & $-0,20$ & 0,11 & $-0,15$ & $-1,86$ & 0,07 \\
\hline Arbejder i operativ specialenhed & 0,16 & 0,12 & 0,11 & 1,38 & 0,17 \\
\hline Arbejder med efterforskning & $-0,18$ & 0,13 & $-0,12$ & $-1,45$ & 0,15 \\
\hline Arbejder med administration eller ledelse & 0,22 & 0,22 & 0,08 & 1,02 & 0,31 \\
\hline Arbejder med forebyggende arbejde & $-0,03$ & 0,26 & $-0,01$ & $-0,13$ & 0,90 \\
\hline Arbejder med efterretning og analyse & 0,06 & 0,56 & 0,01 & 0,11 & 0,91 \\
\hline Konstantled & 2,34 & 0,52 & & 4,49 & 0,00 \\
\hline
\end{tabular}

Tabel 2: Resultater af trinvis regressionsanalyse i forhold til kynisme rettet mod borgerne i Fase 3. Koefficienterne (b) anviser hvordan den estimerede score påvirkes ved 1 points ændring i positiv retning af den uafhængige variabel i forhold til en mandlig deltager fra Skolehold 1 med arbejde i beredskabet ved Fase 3. Høje scorer indikerer høj kynisme.

Ifølge H2 vil høje følelsesmæssige krav, vold og trusler bidrage til øget kynisme hos den enkelte. Resultaterne af regressionsanalysen viste, at modellen samlet set forbedredes marginalt ved at inkludere følelsesmæssige krav, vold og trusler og arbejdsfunktion (justeret $R^{2}: 0,175>0,166$ ). Hverken følelsesmæssige krav, vold og trusler eller funktion havde dog en statistisk signifikant effekt på kynisme ved Fase 3. H2 må derfor afvises. Det kan dog tænkes, at mulighederne for at påvise en eventuel effekt har været svækket af den lange tid mellem Fase 2 og Fase 3 på ca. fire år, idet det må forventes, at betydningen af følelsesmæssige krav, vold og trusler, der ligger tilbage i tiden, vil have en aftagende effekt over tid. Ligeledes vil oplevelser, der ligger tættere på Fase 3, antageligvis have en stærkere sammenhæng med kynisme på dette tidspunkt. Desværre er følelsesmæssige krav, vold og trusler ikke blevet målt i Fase 3. Derfor foretog vi en opfølgende analyse af effekten af følelsesmæssige krav, vold og trusler ved Fase 2 på kynisme i Fase 2 (samme kovariater, men med inddragelse af kynisme mod borgerne ved Fase 1). Denne analyse pegede på en statistisk signifikant sammenhæng mellem både følelsesmæssige krav samt vold og trusler i forhold til udviklingen i kynisme (henholdsvis $b=0,19, p<0,05$ og $b=0,19, p<0,02$.

\section{Diskussion}

Mens forskning til dato anerkender kynisme blandt politifolk som et stort problem, findes der kun få beviser på, hvorledes kynisme udvikler sig over tid. Langt det meste litteratur (Behrend, 1980; Edge et al., 1980; Lotz og Regoli, 1977; Enciso et al., 2017) læner sig op ad Niederhoffers (1967) konklusion og antager således, at politirekrutter bliver mere kyniske, efterhånden som de bliver mere erfarne med arbejdet som betjent. Der kan dog stilles 
spørgsmålstegn ved generaliserbarheden i forhold til en nutidig dansk eller nordisk kontekst, da studierne typisk ikke anvender optimale metoder. Eksempelvis er der typisk anvendt tværsnitsdesigns, kynisme er kun målt som et samlet begreb, og der er ikke gennemført opfølgende undersøgelser, der kan forklare hvilke specifikke forhold, der bidrager til udviklingen i kynisme. Herudover er mange af studierne er af ældre dato eller tager udgangspunkt i lande med en politikultur, der adskiller sig betydeligt fra vores. Nyere nordiske studier peger på, at der ikke nødvendigvis udvikles kynisme mod borgerne under politiuddannelsen (Thomassen et al., 2008; Thomassen og Strype, 2020), men der mangles fortsat viden om, hvad der sker efter endt uddannelse.

Samlet set peger vores resultater på et mere nuanceret billede af, hvordan kynismen udvikler sig hos politifolk, end det vi ser i den internationale forskningslitteratur. Figur 2 viser at den samlede kynisme blandt politifolk under uddannelse og i deres første år i arbejdet følger en »U«-formet udvikling, som først aftager for herefter at stige igen til samme niveau. Figuren viser dog også, at der er tale om meget forskellige udviklinger i kynismens tre delaspekter. I forhold til kynisme rettet mod borgerne ses et statistisk signifikant fald i løbet af uddannelsen og ingen udvikling i den første periode af arbejdslivet. I forhold til retssystemet ses derimod en betydelig stigning, der indtræder i perioden efter endt uddannelse. I forhold til politiets metoder ses en mellemting: først et betydeligt fald i løbet af uddannelsen, og senere en mindre stigning efter endt uddannelse, dog fortsat væsentligt lavere end i udgangspunktet.

Vores resultater viser således, at det er vigtigt at foretage målinger efter endt uddannelse, da udviklingerne under og efter uddannelsen kan være direkte modsatrettede. Men resultaterne peger også på, at man bør være forsigtig med at fortolke på udviklingen i den samlede kynisme. Den første del af arbejdslivet er forbundet med en stigende kynisme, men kun i forhold til de dele af politiets arbejdsvilkår, som ikke vedrører den direkte kontakt med borgerne, svarende til organisatorisk kynisme (Encisco et al., 2017). I forhold til kynisme mod borgerne fandt vi nemlig, at denne var decideret faldende under politiuddannelsen, og ikke steg $\mathrm{i}$ arbejdslivet. Vores resultater nuancerer således Thomassen og Strypes (2020), der kun så et fald hos svenske politistuderende.

Der kan gives forskellige teoretiske bud på faldet i kynisme i forhold til borgerne og det midlertidige fald i forhold til politiets metoder mellem Fase 1 og 2. På den ene side kan man overveje, om politistuderende er præsocialiserede (Thomassen og Strype, 2020) til at have negative forventninger til eksempelvis mødet med borgerne og deres handlemuligheder i politiarbejdet. Fra dette perspektiv kan det tænkes, at kynismen falder på grund af, at de studerende får større kendskab til, hvad politiarbejdet reelt indebærer. Fokuserer vi på kynismen i forhold til borgerne i et nordisk perspektiv, er det dog interessant, at vi hos Thomassen og Strype (2020) 
sammenholdt med vores resultater ser en tendens til, at kynismen falder under uddannelsen i lande med relativt høj kynisme (Danmark og Sverige), mens den stiger i områder med lavere kynisme (Norge og Catalonien). Denne centrering kunne pege på, at de studerende komparativt set påbegynder deres uddannelser med forskellige forventninger i de enkelte lande, men at de udfordringer, de studerende møder under uddannelsen er sammenlignelige.

Stigningerne for to af kynismens tre delaspekter i starten af arbejdslivet kunne dog også pege på en uddannelseseffekt. Med dette mener vi, at politistuderende tilegner sig en måde at forstå forskellige forhold ved politiarbejdet, som gør, at disse vurderes mindre negativt ved slutningen af uddannelsen, men som potentielt udfordres i mødet med det daglige arbejde. Det kan eksempelvis tænkes, at politiuddannelsen udgør et mere legalistisk og teoretisk refleksivt miljø end de arbejdspladser, politifolkene skal indgå i efter endt uddannelse. Denne forklaringsmodel synes at være i overensstemmelse med Bäcks (2015) studie, der viser, at der sker markante fald i svenske politistuderendes behov for refleksiv viden om hvordan man eksempelvis bliver mere tolerant, træffer etiske beslutninger og udviser empati med andres situation samt professionsspecifik viden om metoder, regler og procedurer fra de starter uddannelsen til de afslutter den. Sammenholdt med nordisk forskning, som viser at politistuderende i høj grad er altruistisk motiverede, når de starter på uddannelsen (Sundström og Wolming, 2014), kan faldet i de to delaspekter af kynisme i vores undersøgelse mellem fase 1 og 2 således fortolkes som et udtryk for, at de studerende får opfyldt deres behov for viden på de respektive områder. Dermed bliver politiuddannelsen i de Nordiske lande som eksempelvis Danmark en slags buffer, der bremser de studerendes udvikling hen mod en mere kynisk indstilling, fordi den indeholder studie af og refleksion over kriminologiske teorier og kriminalitetsforebyggelse. I modsætning til dette tilbyder politiuddannelser i f.eks. angelsaksiske lande i højere grad viden af generel karakter (Hove og Vallès, 2020). Respondenterne i vores undersøgelse gennemførte politiuddannelsen som en treårig professionsbachelor, der var kendetegnet ved højt niveau af både teoretisk viden og praktiske færdigheder. Sidenhen er politiuddannelsen i Danmark blevet reduceret i både varighed og akademisk indhold, hvorfor samme store uddannelseseffekt måske ikke er at finde hos efterfølgende kohorter. Dette vil være relevant at undersøge på baggrund af data indsamlet efter ændringen af uddannelsen.

Et formål med artiklen var også at undersøge, om udviklingen i kynisme mod borgerne hænger sammen med særlige forhold ved den enkelte politibetjents arbejde. Vores primære analyser har ikke kunnet påpege systematiske forskelle i denne retning. Dog pegede vores sekundære analyse på, at eksponering for høje følelsesmæssige krav eller vold og trusler forudsagde udviklingen i kynisme, når disse blev målt på samme tidspunkt. Selv om det metodemæssigt 
kan være ønskeligt at måle eksponeringen før effekten, kan det tænkes, at den lange opfølgningstid i RECPOL-undersøgelsen reducerer en eventuel sammenhæng. Det havde således været relevant, at spørgsmålene om vold og trusler også havde været inkluderet i undersøgelsens Fase 3. Der kan dog også være andre relevante faktorer ift. kynisme, end de, vi har undersøgt her, såsom personlighed. Forskningen har dog indtil videre kun spekuleret i, at der muligvis kunne være en sammenhæng mellem personlighed og kynisme blandt politifolk (Twersky-Glasner, 2005).

En fejlkilde i undersøgelsen er, at svarprocenten i Fase 3 var lavere end i de første to faser. Vores analyser peger dog ikke på et generelt selektivt frafald. Det er iøjnefaldende, at en større andel af de kvindelige deltagere falder fra, men dataene giver ikke mulighed for at sige, om frafaldet for eksempel skyldes lavere tilbøjelighed til at svare, at flere kvinder har fået ansættelse uden for politiet eller at en større del er på orlov. Dog må der forventes en lavere svarprocent, når der er tale om spørgeskemaundersøgelser med lang opfølgningstid. Derimod styrker det datamaterialet, at svarprocenten i de to første faser er forholdsvis høj. Samlet peger vores resultater på vigtigheden af studier med lang opfølgningstid, foretaget i en kontekst der er sammenlignelig med dén, man ønsker at generalisere til. Det synes også relevant at være opmærksom på følelsesmæssige krav, vold og trusler som mulige risikofaktorer i forhold til at udvikle kynisme, om end vi stadig mangler viden om denne udvikling.

Selv om der ikke sker en egentlig stigning i kynismen i forhold til borgerne efter endt uddannelse, så giver respondenternes besvarelser overordnet indtryk af, at kynisme er udbredt blandt i alle fald en del af respondenterne. Med øje for de seneste års øgede samfundsmæssige fokus på at forbedre politiets kontakt med borgerne, er der behov for at fastholde et fokus på, hvad der bidrager til kynisme i en dansk og nordisk kontekst, om kynismens følgevirkninger, og om hvordan den kan forebygges eller reduceres.

\section{Konklusion}

I den internationale politiforskning beskrives det, at politifolk tidligt i deres karriere kan udvikle kynisme, forstået som en kritisk indstilling præget af mistro eller pessimisme, der ofte er rettet mod borgerne. Mens der de senere år har været et øget samfundsmæssigt fokus på, hvordan borgerne generelt oplever kontakten med politiet, er der dog fortsat kun begrænset viden om udviklingen af kynisme i en skandinavisk, herunder en dansk kontekst. I denne artikel har vi undersøgt udviklingen i kynisme og dennes delaspekter ved at følge de samme danske politifolk over en syvårig periode, fra starten af deres uddannelse og frem til fire års aktiv tjeneste. Resultaterne peger på, at kynisme bør ses som et sammensat fænomen, i og med at deltagerne generelt bliver mindre kyniske i forhold til borgerne, men mere kyniske i forhold til andre dele af politiarbejdet, herunder det 
strafferetslige system og politiets arbejdsmetoder. Supplerende analyser indikerer dog, at høje følelsesmæssige krav, vold eller trusler muligvis kan bidrage til øget kynisme rettet mod borgerne.

Forfatterne ønsker at takke Sahar Yasen for hendes værdifulde hjælp i forbindelse med databearbejdningen og forberedelsen af analyserne.

\section{Finansiering}

Denne artikel udspringer af et forskningsprojekt, som er støttet økonomisk af Offerfonden.

De vurderinger og synspunkter, der fremgår af artiklen, er forfatternes egne og deles ikke nødvendigvis af Rådet for Offerfonden.

Kontaktoplysninger

Christian Dyrlund Wåhlin-Jacobsen: cdw.ioa@cbs.dk

Elisabeth Naima Mikkelsen enm@ioa.dk

\section{Litteratur}

Andersson, L. M., \& Bateman, T. S. (1997). Cynicism in the workplace: Some causes and effects. Journal of Organizational Behavior: The International Journal of Industrial, Occupational and Organizational Psychology and Behavior, 18(5), 449-469. https://doi. org/10.1002/(sici)1099-1379(199709)18:5<449::aid-job808>3.0.co;2-o

Behrend, K. R. (1980). Police cynicism: A cancer in law enforcement. FBI L. Enforcement Bull., 49, 1.

Bjørgo, T., \& Damen, M.-L. (Eds.). (2020). The making of a police officer: Comparative perspectives on police education and recruitment. Oxon, UK: Routledge. https://doi. org/10.4324/9780429277221

Bäck, T. (2015). Police students' values of competence related to a professional career. In Working and learning in times of uncertainty (pp. 89-101). SensePublishers, Rotterdam. https://doi.org/10.1007/978-94-6300-244-8_7

Caplan, J. (2003). Police cynicism: police survival tool? The Police Journal, 76(4), 304-313. https://doi.org/10.1350/pojo.76.4.304.25821

Edge, J. R., Buffington, P. W., \& Slemons, D. E. (1980). Anxiety and cynicism: companions of the police officer. American Journal of Criminal Justice, 5(2), 18-24. https://doi. org/10.1007/bf02887384

Enciso, G., Maskaly, J., \& Donner, C. M. (2017). Organizational cynicism in policing. Policing: An International Journal of Police Strategies \& Management, 40(1), 86-98. https://doi. org/10.1108/pijpsm-07-2016-0120

Fekjær, S. B., Petersson, O., \& Thomassen, G. (2014). From legalist to Dirty Harry: Police recruits' attitudes towards non-legalistic police practice. European Journal of Criminology, 11(6), 745-759. https://doi.org/10.1177/1477370814525935

Ford, R. E. (2003). Saying One Thing, Meaning Another: The Role of Parables in Police Training. Police Quarterly, 6(1), 84-110. https://doi.org/10.1177/1098611102250903

Gallup (2020). Confidence in Institutions, June 8-July 24, 2020. Hentet fra https://news. gallup.com/file/poll/317168/200811ConfByRace.pdf

Goodman, J. S., \& Blum, T. C. (1996). Assessing the Non-Random Sampling Effects of Subject Attrition in Longitudinal Research. Journal of Management, 22(4), 627-652.

Graves, W. (1996). Police cynicism: Causes and cures. FBI L. Enforcement Bull., 65, 16.

Hove, K. (2012). Kompetansebehov hos nytilsatt politi. Nordisk Tidsskrift for Kriminalvidenskab, 99(1), 77-96. https://doi.org/10.7146/ntfk.v99i1.71785 
Hove, K., \& Vallès, L. (2020). Police education in seven European countries in the framework of their police systems. The Making of a Police Officer: Comparative Perspectives on Police Education and Recruitment, 18-54. https://doi.org/10.4324/9780429277221-3

Hunt, J. (1985). Police accounts of normal force. Urban Life, 13(4), 315-341. https://doi. org/10.1177/0098303985013004001

Justitsministeriet (2017). Politiets møde med borgerne. København: Justitsministeriet.

Justitsministeriet (2018). Nærhed og tryghed. København: Justitsministeriet

Justitsministeriets Forskningskontor (2016). Tryghed og holdning til politi og retssystem. Danmark i forhold til andre europæiske lande. København: Justitsministeriet.

Justitsministeriets Forskningskontor (2018). Borgernes tilfredshed med politiet. København: Justitsministeriet.

Kjelmann, K. G., \& Møberg, R. J. (2018). Hvem er de politistuderende, og hvilke forestillinger gør de sig om politiarbejdet? Rapport, AAU.

Kääriäinen, J., \& Sirén, R. (2012). Do the police trust in citizens? European comparisons. European Journal of Criminology, 9(3), 276-289. https://doi.org/10.1177/1477370811435737

Langworthy, R. H. (1987). Police cynicism: What we know from the Niederhoffer scale. Journal of Criminal Justice, 15(1), 17-35. https://doi.org/10.1016/0047-2352(87)90075-4

Lotz, R., \& Regoli, R. M. (1977). Police cynicism and professionalism. Human Relations, 30(2), 175-186. https://doi.org/10.1177/001872677703000206

Mignone, A. (2005). Arthur Niederhoffer's study on police cynicism among NYPD recruits. Honors College Theses. Paper 20.

Niederhoffer, A. (1967). Behind the shield: The police in urban society. NY: Doubleday.

Poole, E. D., \& Regoli, R. M. (1979). Police professionalism and cynicism: An empirical assessment. Criminal Justice and Behavior, 6(2), 201-206. https://doi. org/10.1177/009385487900600208

Regoli, R. M. (1976). An empirical assessment of Niederhoffer's police cynicism scale. Journal of Criminal Justice, 4(3), 231-241. https://doi.org/10.1016/0047-2352(76)90005-2

Regoli, R. M., Crank, J. P., Culbertson, R. G., \& Poole, E. D. (1987). Police professionalism and cynicism reconsidered: An assessment of measurement issues. Justice Quarterly, 4(2), 257-275. https://doi.org/10.1080/07418828700089301

Regoli, B., Crank, J. P., \& Rivera, G. (1990). The construction and implementation of an alternative measure of police cynicism. Criminal Justice and Behavior, 17(4), 395-409. https://doi.org/10.1177/0093854890017004001

Richardsen, A.M., Burke, R.J., \& Martinussen, M. (2006). Work and health outcomes among police officers: the mediating role of police cynicism and engagement. International Journal of Stress Management, 13(4), 555-574. https://doi.org/10.1037/10725245.13.4.555

Rigspolitiet (2020). Politiets Tryghedsundersøgelse 2019. København: Rigspolitiet.

Sobol, J. J. (2010). The social ecology of police attitudes. Policing: An International Journal of Police Strategies \& Management, 33(2), 253-269. https://doi. org/10.1108/13639511011044876

StataCorp (2019). Stata SE 16.1. College Station, USA: StataCorp LLC

Sundström, A., \& Wolming, S. (2014). Swedish student police officers' job values and relationships with gender and educational background. Police Practice and Research, 15(1), 35-47. https://doi.org/10.1080/15614263.2013.815385

Thomassen, G., Larsson, P., \& Strype, J. (2008). Politics in the police: What are the implications of political diversity? In R. Granèr \& P. Larsson (Eds.), Policing in Scandinavia. Växsjö: Växjö University Studies in Policing. https://doi.org/10.1093/police/pat032

Thomassen, G., \& Strype, J. (2020). Cynicism and (dis) trust in the police. I Bjørgo, T., \& Damen, M.-L. (Eds.). (2020). The making of a police officer: Comparative perspectives on police education and recruitment, 194-207. https://doi.org/10.4324/9780429277221-12 
Travis, L. F., \& Vukovich, R. J. (1990). Cynicism and job satisfaction in policing: Muddying the waters. American Journal of Criminal Justice, 15(1), 90-104. https://doi.org/10.1007/ bf02887458

Twersky-Glasner, A. (2005). Police personality: What is it and why are they like that? Journal of Police and Criminal Psychology, 20(1), 56-67. https://doi.org/10.1007/bf02806707

\section{Bilag: Items anvendt i skalaer, der indgår i artiklen}

\subsection{Kynisme}

Her finder du nogle udsagn om politiet og samfundet. Vi beder dig markere i hvilken grad, du er enig eller uenig i hvert af udsagnene

- Nye forandringer og reformer svækker politifolks traditionelle autoritet

- Lovovertrædere har så mange rettigheder, at det praktisk talt er umuligt at opretholde lov og orden

- Politiet burde have ret til at aflytte og optage telefonsamtaler, hvis de finder, det er nødvendigt

- Når en person bliver anholdt, bør vedkommende holdes i varetægt, indtil sagen kommer for retten, hvis politiet og anklageren finder, at det er nødvendigt

- Mange borgere har en negativ holdning over for politifolk.

- I løbet af de seneste år er den respekt, borgerne viser politiet, dalet.

- Det virker som om at, borgerne de senere år har mere trodsige holdninger end nogensinde før.

- Når politifolk optræder som vidner i retten, bliver de ofte behandlet som kriminelle

\subsection{Følelsesmæssige krav}

I hvor høj grad oplever du følgende i forbindelse med dit arbejde?

- Jeg bliver følelsesmæssigt berørt af mit arbejde.

- Mit arbejde kræver, at jeg skal skjule, hvad jeg egentlig føler.

- Jeg kan nemt udtrykke positive følelser for borgerne, som det forventes i mit job.

- Mit arbejde bruger mig i følelsesmæssigt belastende situationer.

- Jeg skjuler min vrede over noget en borger har gjort.

- Jeg skjuler min frygt overfor borgere som er truende overfor mig.

- Jeg skjuler, at jeg egentlig er ligeglad med det borgeren har oplevet.

- Jeg har svært ved at bevare tålmodigheden i mødet med borgere.

- Jeg har svært ved at fremvise autoritet over for borgere.

- Jeg oplever det som frustrerende at skulle tale konflikter ned.

- Jeg synes det er anstrengende at skulle være venlig og imødekommende over for alle-uanset hvordan de er over for mig.

\subsection{Vold og trusler}

Har du i løbet af dine praktikperioder været udsat for

- ... trusler om vold

- ... at modtage skriftlige trusler

- ... at blive kaldt ubehagelige og nedværdigende ting på truende vis

- ... at blive truet med genstande

- ... indirekte trusler 'jeg ved hvor du bor/hvor dine børn går i skole')

- ... fysisk vold

_... at blive skubbet til

- ... at blive spyttet på 